\title{
A new boletoid fungus, Boletus pinetorum, in the Boletus section Boletus from Fennoscandia (Basidiomycota, Boletales)
}

\author{
MAURI KORHONEN, KARE LIIMATAINEN and TUULA NISKANEN
}

\begin{abstract}
KORHONEN, M., LIIMATAINEN, K. AND NISKANEN, T. 2009: A new boletoid fungus, Boletus pinetorum, in the Boletus section Boletus from Fennoscandia (Basidiomycota, Boletales). - Karstenia 49: 41-60. Helsinki. ISSN 0453-3402.

A detailed study of morphological characters of the species in the Boletus sect. Boletus occurring in Finland was carried out. Consequently six species were separated: $B$. pinophilus, B. reticulatus, and four species in the B. edulis group: B. edulis, B. betulicola, $B$. aff. reticulatus and $B$. pinetorum $M$. Korhonen spec. nov. In addition, the identity of $B$. edulis var. arcticus is discussed. The species presented in this study have good distinguishing macro- and especially microscopical characters as well as differences in their ecological requirements. The most useful microscopical characters used for distinguishing the species are: shape of the spores, caulocystidia, and characters of pileipellis hyphae. A phylogenetic study of the species was also undertaken using the molecular markers ITS1 and ITS2. In addition, the IGS1 region of B. edulis coll. and $B$. pinophilus was studied. A total of 46 sequences were generated. The IGS1 region was shorter than ITS1-5.8S-ITS2 region and interestingly contained less intraspecific variation than ITS1 and ITS2. In our analysis Boletus pinophilus, B. reticulatus, and B. edulis s. lato formed well supported lineages but as in previous studies, relationships inside the $B$. edulis group remained unresolved. Based on their distinct macro- and microscopical characters, however, we consider the taxa within B. edulis groups as separate species.
\end{abstract}

Key words: taxonomy, Boletales, Boletus, IGS, ITS

M. Korhonen, Botanical Museum, P.O Box 7, FI-00014 University of Helsinki, Finland; e-mailmauri.korhonen@helsinki.fi

K. Liimatainen and T. Niskanen, Department of Biological and Environmental Sciences, Plant Biology, P.O. Box 65, FI-00014 University of Helsinki, Finland; e-mail: kare. liimatainen@helsinki.fi,tuula.niskanen@cortinarius.fi

\section{Introduction}

Boletus section Boletus is a well defined group based on morphology and molecular data (Binder 1999, Singer 1986). Typical for the species in this section are the reticulate surface of the stipe, whitish pores which become yellowish green with age, and white context.

Although the delimitation of the section seems to be clear the same does not apply to the species. A lot of different opinions about the number of species and their delimitation have been presented. Van der Linde (2004) did an extensive study of the European species of the section Boletus and ended up in distinguishing four species: $B$. aereus, $B$. pinophilus, B. reticulatus, and $B$. edulis. In addition he recognized three morphotypes within B. edulis which differed from one another mainly by the colouration of the pileus and their ecology. This classification was further studied by Beugelsdijk et al. (2008) using the molecular markers ITS1, ITS2 and GAPDH. Four lineages, $B$. aereus, $B$. pinophilus, $B$. reticulatus, and $B$. edulis were clearly separated in their phylogenetic analysis but no support was found for the taxa inside B. edulis group. Therefore, Beugelsdijk et 
al. concluded that B. edulis is just a very variable species associated with several different tree species. Similar kinds of results were also gained by Leonardi et al. (2005) in their study of the $B$. edulis complex from Italy and France.

The ITS region is widely used in the species level taxonomy of many Basidiomycetes and in general it seems to be very suitable for that purpose. In some studies, however, this is not the case. Den Bakker et al. (2004) used GAPDH in addition to ITS2 for distinguishing some species of Leccinum, and Aanen et al. (2000) found out that IGS might be better than ITS for distinguishing biological species in Hebeloma.

The first author of this paper has studied the species of the section Boletus for over 25 years. In 2000 (Korhonen 2000), he suggested that there is a distinctive species with in the $B$. edulis group that grows in Fennoscandian pine heaths, and that it differed from the others not only by the macromorphology and ecology but also based on microscopical features - the latter often being overlooked in the earlier studies of this species group. The aim of this study was to compare all the species of the Boletus sect. Boletus occurring in Finland and to present the morphological characters separating them as well as to study the species level taxonomy based on ITS and IGS1 regions.

\section{Materials and methods}

The majority of the material for this study was collected by M. Korhonen from different parts of Fennoscandia during the last 25 years. Some collections, collected by Ilkka Kytövuori and Paavo Höijer, were also included. All the collections are or will be deposited or will be in the herbarium H. For the detailed morphological and DNA studies, different colour variants of each species were chosen to achieve as reliable result as possible.

Macroscopic characters were observed from fresh fruitbodies and several collections were used for the descriptions. For colour pictures the fungi were photographed at the original site in the field, with an Arca Swiss studio camera on a tripod. The colour film was Kodak Ektachrome 100 professional (EPN 120 rollfilm), square $6 \times$ $9 \mathrm{~cm}$ format.

The microscopical study of specimens was conducted with a Leitz Dialux microscope equipped with a Pl Apo Oel 100/1.32 oil immersion lens. Spores, cystidia and pileipellis hyphae were drawn with a Leitz drawing tube at a magnification of 2000. All measurements are based on the drawings, and measurements are corrected down to $1 / 2 \mu \mathrm{m}$. All the preparations were mounted in pure water without use of any softening or colour medium. This allowed the observation of the natural colour of the structures. Spores, cystidia and pileipellis hyphae were studied from dry material. Cheilo- and pleurocystidia were not studied in more detail since they generally have a low diagnostic value in the section Boletus (Knudsen \& Taylor 2008). Spores were examined from hymenophoral material. One fruitbody from each collection listed in the sections of representative specimens was studied. Measurements were made of 50 to 100 spores, and care was taken to ensure that only mature spores were studied. These usually have darker and thicker walls than immature spores. Spores from the hymenium of the stipe were avoided, since those are usually smaller than the ones from the hymenium of the pores. The length/width ratios (Q-value) were calculated for individual spores. Spore volume was calculated according to the formula of an ellipsoid: $4 \times \pi / 3 \times \mathrm{a} \times \mathrm{a} \times \mathrm{b}(\mathrm{a}=$ the radius of the transverse axes; $b=$ the radius of the longitudinal axes; Breitenbach \& Kränzlin 1991). The pileipellis was examined using small scalps ( $1 / 3$ radius from the edge of the cap towards the centre) made with a razor blade. With the same technique mature caulocystidia were studied from the net of the stipe.

A total of 25 collections of $B$. pinetorum, B. reticulatus, $B$. aff. reticulatus, $B$. pinophilus, $B$. edulis and $B$. betulicola were sequenced from the ITS1 and ITS2 regions of the rDNA. Total DNA was extracted from a few milligrams of dried material (a piece from tube layer) using the NucleoSpin Plant kit (Macherey-Nagel). The primers ITS $1 \mathrm{~F}$ and ITS 4 (Gardes \& Bruns 1993; White et al. 1990) were used to amplify the ITS regions. Same primers pairs were used in direct sequencing. PCR amplification and sequencing followed Niskanen et al. (2008).

Sequences were assembled and edited using Sequencher 4.1 (Gene Codes, Ann Arbor). Intragenomic polymorphism was observed as mixed peaks in chromatographic data.

Base polymorphisms are marked with IUB codes (further information is provided upon request).

Boletus fechtneri was used as outgroup and an alignment of 26 ITS sequences for phylogenetic analysis was produced with the Muscle program (Edgar 2004) using default settings and followed by manual adjustments in BioEdit (www.mbio.ncsu.edu/BioEdit/bioedit.html). The original alignment, which was 841 nucleotides long (including gaps), was used for the analysis.

Maximum parsimony (MP) analysis was performed with TNT v.1.0 (Goloboff et al. 2000). The analysis was run using two dual processors of $2.6 \mathrm{GHz}$. A heuristic search strategy with TBR branch swapping, 10000 random replicates, and maxtrees of 10000 was employed. Gaps were treated as a fifth character for the dataset. Bootstrap (BS) values were counted with 10000 replicates. Analysis was run with the computer clusters of the CSC, IT Centre for Science, Espoo, Finland.

Since no support for the taxa within $B$. edulis groups was gained, the IGS1-region of 21 specimens was also amplified and sequenced using the primers CNL12 and 5SA (Henrion et al. 1992). The procedure for PCR amplification and sequencing was the same as for ITS, except the extension time in the first PCR reaction was extended to 1 minute because of the length of the region. In order to understand the closeness of the studied sequences, they were aligned using the ClustalW 1.8 program (Thompson et al. 1994) on the European Bioinformatics Institute server (http://www.ebi.ac.uk/clustalw/index.html). 


\section{Results and discussion of DNA studies}

The analysis of ITS sequences resulted in one most parsimonius tree with the length of 530 steps (Fig. 1). Based on the analysis Boletus pinophilus, B. reticulatus, and B. edulis s. lato formed well supported lineages whereas the taxa within the $B$. edulis clade, $B$. edulis, B. betulicola, $B$. aff. reticulatus and $B$. pinetorum, were not separated.
The taxa were further studied based on their IGS1 region. Boletus pinophilus and B. edulis s. lato had much smaller intraspecific pairwise distances compared to the interspecific ones, but again no significant differences between the species within $B$. edulis group were found. Therefore, no further analyses were carried out.

Most species were genetically polymorphic in ITS1, ITS2 and IGS1 regions and majority

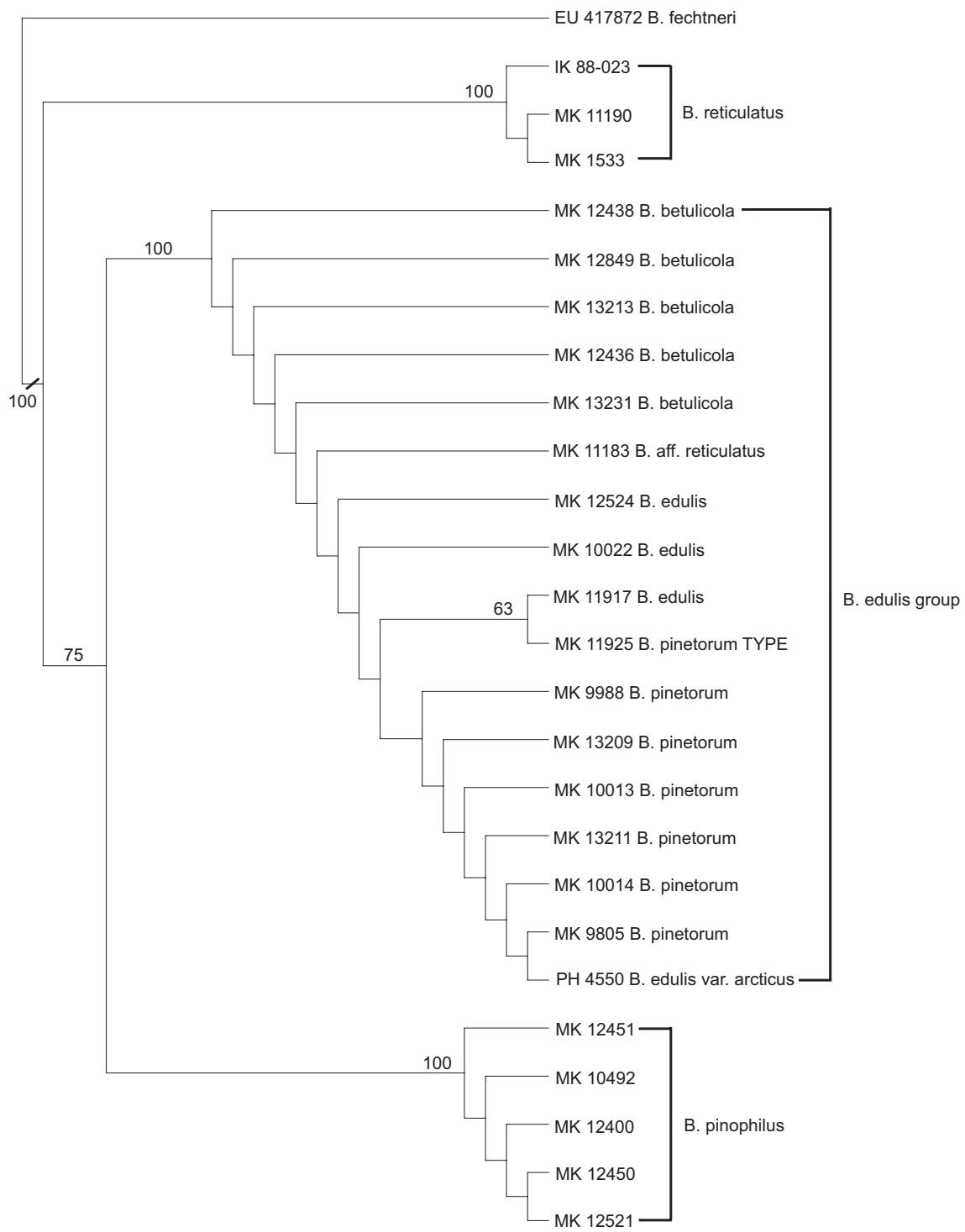

Fig. 1. The most parsimonious tree inferred from ITS regions (including 5.8S). Bootstrap values $>50 \%$ are indicated above branches. IK = I. Kytövuori, MK = M. Korhonen, PH = P. Höijer. 
of these polymorphisms were single base polymorphisms. Intrestingly, IGS1 contained less intraspecific variation than ITS1 and ITS2, and the region was shorter than ITS1-5.8S-ITS2 region. Intragenomic variation within Boletales (Xerocomus) has previously been reported by Taylor et al. (2006) also.

As a conclusion Boletus pinophilus, B. reticulatus, and B. edulis s. lato are well supported in our analysis and based on our IGS1 data but as well as in the previous studies relationships inside the B. edulis group remained unresolved. Based on their distinct macro- and microscopical characters, however, we consider the taxa $B$. edulis, B. betulicola, B. aff. reticulatus and $B$. pinetorum within $B$. edulis groups as separate species.

1. Boletus pinetorum $M$. Korhonen, spec. nova - Figs. 2 and 8, Tables 1-3

MycoBank No.: MB 515526

Sicut Boletus pinophilus sed pileus griseobrunneus et stipes superficie reticulo albo; caulocystidiis majoribus $(70-160 \times 13-30 \mu \mathrm{m}$, basi expansis) et sporis majoribus (16.5-19 × 5.5-6.5 $\mu \mathrm{m}$, volumine mediocriter $\left.308 \mu \mathrm{m}^{3}\right)$. Una cum Pino sylvestri crescens.

Typus: Finland. Uusimaa: Hanko, $1 \mathrm{~km} \mathrm{~N}$ of Tvärminneby, in a dry pine forest (Pinus sylvestris) on sand, 24 Sep1994 Korhonen 11925 (H - holotypus, NY - isotypus). GenBank no. GU198995.

Pileus 15-25 (-30) cm, greyish brown, sometimes yellowish brown or dark brown, smooth to almost smooth, edge \pm wrinkled, surface matt when dry, slightly viscid when wet. Hymenophore tubulate, tubes $2-4 \mathrm{~cm}$ long, at first yellow, then greenish yellow and finally greyish yellow-green. Pores concolorous with tubes, small. Stipe 13-17 cm long, cylindrical or swollen below, whitish with a brownish tint; with a distinct, white reticulum, meshes at the top of stipe approximately $3 \times 0.5-1 \mathrm{~mm}$, at the base even $10 \times$ $2 \mathrm{~mm}$. Context white, under pileipellis yellowish brown, firm when young, later soft. Taste pleasant. Smell pleasant, strong.

Spores 16.5-19 × 5.5-6.5 $\mu \mathrm{m}, \mathrm{Q}=2.8-3.3$ (600 spores, 12 collections), $\mathrm{X}(\mathrm{av})=.17.5 \times 5.8$ $\mu \mathrm{m}, \mathrm{Q}(\mathrm{av})=3.05,. \mathrm{Vm}=308 \mu \mathrm{m}^{3}$, (Fig. 8) fusiform, smooth, yellowish brown, thick-walled.
Basidia 4-spored, 23-30 × 6-9 $\mu \mathrm{m}$, slightly clavate to cylindrical. Caulocystidia 70-160 $\times$ 13-30 $\mu \mathrm{m}$, lageniform. Cells of the pileipellis hyphae long, variably brown, some very dark. Endcells of pileipellis 30-60 ×6-12 $\mu \mathrm{m}$, cylindrical or slightly clavate, almost hyaline.

Ecology and distribution: Boletus pinetorum is associated with Pinus sylvestris, It is common in dry sandy pine heaths as well as in dryish to submesic coniferous forests. It fruits in habitats similar to $B$. pinophilus and comparatively late in summer, later than B. edulis. Boletus pinetorum is known from Scandinavia, Finland and Estonia.

Comments: Boletus pinetorum resembles $B$. edulis, but it has a greyish brown pileus with a wrinkled edge, and grows with Pinus. The caulocystidia of $B$. pinetorum are lageniform.

Representative specimens examined: FINLAND. Varsinais-Suomi: Paimio, 4 Sept 1990 Korhonen 9805 (ITS GU198989, IGS GU223353). Länsi-Turunmaa (Parainen), Lapplahti, 10 Sept 1992 Korhonen 11166 photo. Uusimaa: Hanko, Krogars, 28 Sept 1990 Korhonen 10013 photo (ITS GU198991, IGS GU223351), 28 Sept 1990 Korhonen 10014 (ITS GU198993, IGS GU223348); Tvärminneby, 13 Sept 1986 Korhonen 7255 , 24 Sept 1994 Korhonen 11925 photo (holotype H, isotype NY; ITS GU198995). Raasepori, Bromarv, 27 Sept 1983 Korhonen 5653 (IGS GU223349); Tenhola, 25 Sept 1990 Korhonen 9988 photo (ITS GU198990, IGS GU223354). Vantaa, Veromies, 21 Aug 1992 Korhonen 10954 photo, 30 Sept 1994 Korhonen 11958. - NORWAY. Troms: Skibotn, Furumoen, 20 Aug 2003 Korhonen 13209 (ITS GU198994, IGS GU223352), 20 Aug 2003 Korhonen 13211 photo (ITS GU198992, IGS GU223350).

2. Boletus edulis Bull.: Fr. - Figs. 3 and 8 , Tables 1-3

Boletus edulis Bull., Herbier de la France 2: tab. 60. 1782. (Sanctioned in Fries, 1821, Syst. mycol. 1: 392).

Pileus 10-25 $(-30) \mathrm{cm}$, pale brown, yellowish brown to dark brown, surface slightly viscid, glutinous when wet. Hymenophore tubulate, tubes $2-3 \mathrm{~cm}$ long, first yellowish, then greenish yellow. Pores whitish when young, then concolorous with tubes, small. Stipe 10-15 cm long, cylindrical or swollen below, whitish with a brownish tint; with a fine, white reticulum, best seen at the top of stipe. Context white, under pileipellis reddish brown, firm when young, later soft. Taste mild, pleasant. Smell pleasant. 
Spores 16-19 × 5-6 $\mu \mathrm{m}, \mathrm{Q}=2.7-3.4(350$ spores, 7 collections), $\mathrm{X}(\mathrm{av})=.17 \times 5.5 \mu \mathrm{m}$, $\mathrm{Q}(\mathrm{av})=3.05,. \mathrm{Vm}=269 \mu \mathrm{m}^{3}$, (Fig. 8) fusiform, smooth, yellowish brown, thick-walled. Basidia 4-spored, 23-27 × 6-7.5 $\mu \mathrm{m}$, clavate, distinctly broader at the top, base slender. Caulocystidia 70-110 × 5-10 $\mu \mathrm{m}$, cylindrical or somewhat swollen below. Hyphae of the pileipellis short, granulated, more or less brownish. End-cells of pileipellis $15-30 \times 5-15 \mu \mathrm{m}$, short, cylindrical or slightly clavate.

Ecology and distribution: Boletus edulis is associated with Picea abies and occurs in the distribution area of its host. It prefers submesic heath forests and is somewhat acidophilous. It has not been recorded from subalpine regions. Boletus edulis is common and abundant in Fennoscandia, although differences in yearly fruitbody production can be big.

Comments: Boletus edulis has variably brown cap, yellow, with age outwards swelling hymenophore, and white reticulum on stipe. It is associated with Picea abies and occurs in all parts of Europe, especially in montane spruce forests and in spruce plantations. This contrasts with the other species of $B$. edulis groups which either associate with deciduous trees or Pinus sylvestris.

A form of Boletus edulis also occurs with $\mathrm{Fa}$ gus. Its spores are large $16-21 \times 5.5-6.5 \mu \mathrm{m}$, caulocystidia are long and narrow, and the hyphae of the epicutis are narrow and cylindrical (Fig. 9, Tables 1-3, specimen examined: FRANCE. Environ de Belfort, 8 Oct 1998 Korhonen 12794).

Representative specimens examined: FINLAND. Uusimaa: Hanko, Tvärminneby, 28 Sept 1990 Korhonen 10022 ${ }^{\mathrm{D}}$ (ITS GU198977, IGS GU223357). Raasepori, Bromarv, 5 Aug 2000 Korhonen 12949 (IGS GU223358); Tenhola, 20 Sept 1997, Korhonen 12524 photo (ITS GU198975, IGS GU223355). Vantaa, Veromies, 23 Sept 1994 Korhonen 11917 photo (ITS GU198976, IGS GU223356), 23 Sept 1994 Korhonen 11924. EteläHäme: Loppi, Läyliäinen, Haapastensyrjä, 22 Sept 2007 T. Timonen \& Korhonen 14525; Pursuntie, 12 Sept 2004 T. Timonen \& Korhonen 14094 photo.

3. Boletus pinophilus Pilát \& Dermek - Figs. 4 and 9, Tables 1-3

Boletus pinophilus Pilát \& Dermek, Česká Mykol. 27(1): 6. 1973.

Pileus 10-25 $(-30) \mathrm{cm}$, ochraceous greyish brown, date brown, greyish brown, brown, red- dish brown to dark reddish brown, surface often wrinkled-rugose, matt and with a frosted appearance when young, greasy when old and with whitish edge, viscid or even glutinous when wet. Hymenophore tubulate, tubes 3-4 cm long, first yellowish, then yellowish green, with age outwards swollen. Pores whitish to yellowish when young, then \pm reddish brown, first becoming pale bluish green then rusty brown when bruised or damaged, small. Stipe $10-16 \mathrm{~cm}$, swollen at the base, stout, concolorous but paler than the pileus; with whitish to pale brownish reticulum. Context white, under pileipellis distinctly reddish brown, firm. Taste mild, pleasant. Smell strong, pleasant.

Spores $17-20 \times 4.5-6 \mu \mathrm{m}, \mathrm{Q}=3-3.8(500$ spores, 10 collections), $X($ av. $)=18 \times 5.5 \mu \mathrm{m}$, $\mathrm{Q}(\mathrm{av})=3.4,. \mathrm{Vm}=285 \mu \mathrm{m}^{3}$, (Fig. 9) fusiform, smooth, yellowish brown, thick-walled. Basidia 4-spored, 27-35 × 7-8 $\mu \mathrm{m}$, clavate. Caulocystidia 58-66 × 10-14 $\mu \mathrm{m}$, cylindrical to slightly lageniform. Hyphae of the pileipellis more or less granulated and variable brown. End-cells of pileipellis $25-90 \times 14-35 \mu \mathrm{m}$, distinctly inflated, incrusted.

Ecology and distribution: Boletus pinophilus is associated with Pinus sylvestris. It is most abundant in dry pine heath forests on sandy soil but occurs in many other kinds of coniferous forests, too. It is common to very common in Fennoscandia but occasional in Denmark where it is most common in Jylland. In other parts of Europe it occurs at least in montane coniferous forests.

Comments: Typical for Boletus pinophilus are the reddish brown pileus, \pm reddish brown pores which become pale bluish green to rusty brown when bruised or damaged, and habitat with pine. Microscopically the species can be distinguished from the other species of the section Boletus by the distinctly inflated, incrusted end-cells of the pileipellis. Sometimes the pigment particles may, however, detach and then they are easily overlooked.

Representative specimens examined: FINLAND. Uusimaa: Hanko, Tvärminneby, 28 Sept 2004 Korhonen 14121. Raasepori, 12 Sept 1991 Korhonen 10492 photo (ITS GU198988, IGS GU223343), 23 Sept 2004 Korhonen 14114; Bromarv, 17 Sept 1992 Korhonen 11243 photo, 18 Sept 1997 Korhonen 12521 (ITS GU198986, IGS GU223344), 12523. Satakunta: Harjavalta, 23 Sept 1992 Korhonen 11264 photo. Pohjois-Karjala: Ilomantsi, Mekrijärvi, 17 Aug 1997 Korhonen 12450 photo (ITS GU198984, IGS GU223342), 17 Aug 1997 Kor- 


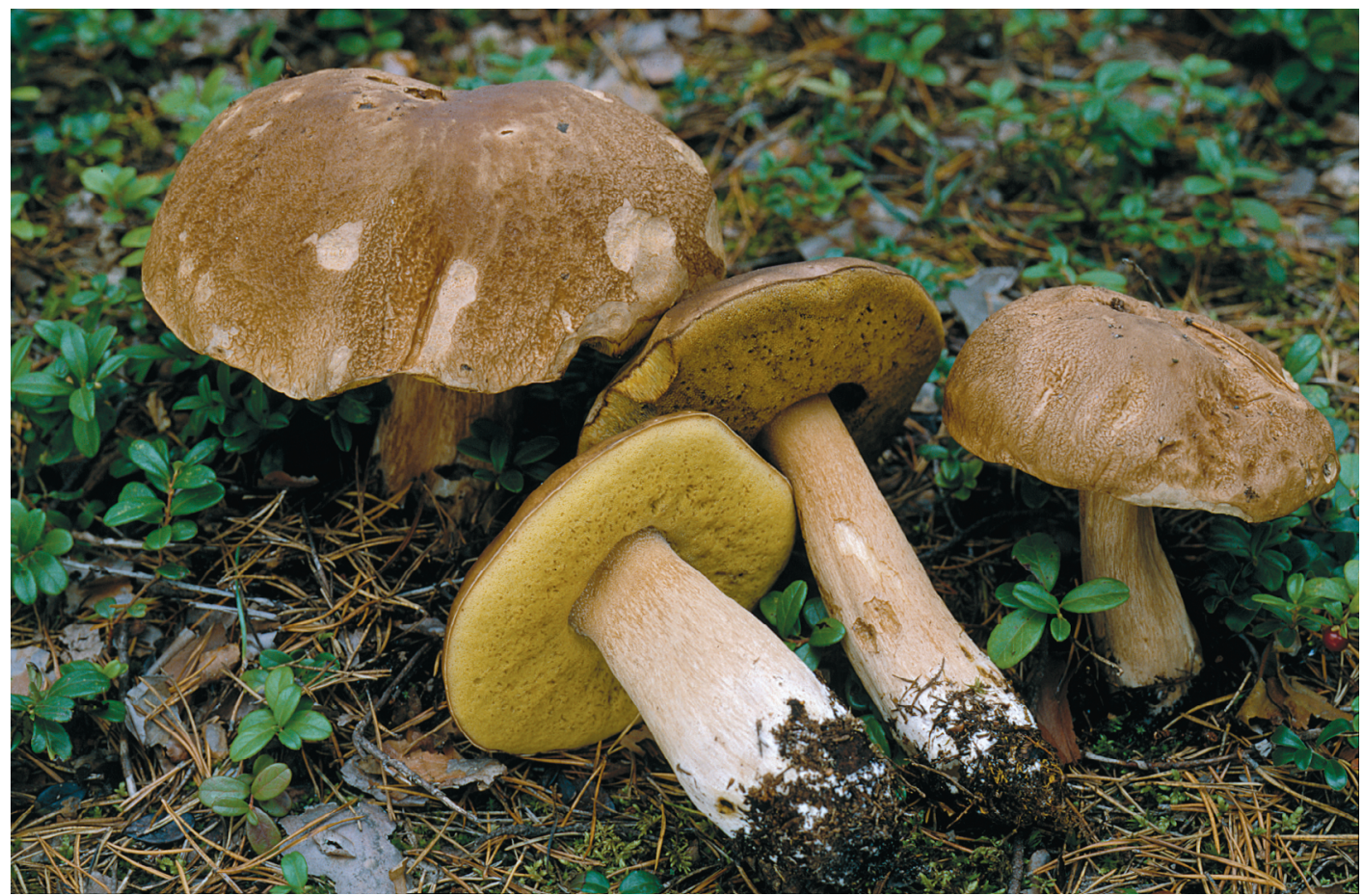

Fig. 2. Boletus pinetorum, Finland, Uusimaa, Hanko, Tvärminneby, 1994 Korhonen 11925 (holotypus). Photo M. Korhonen.

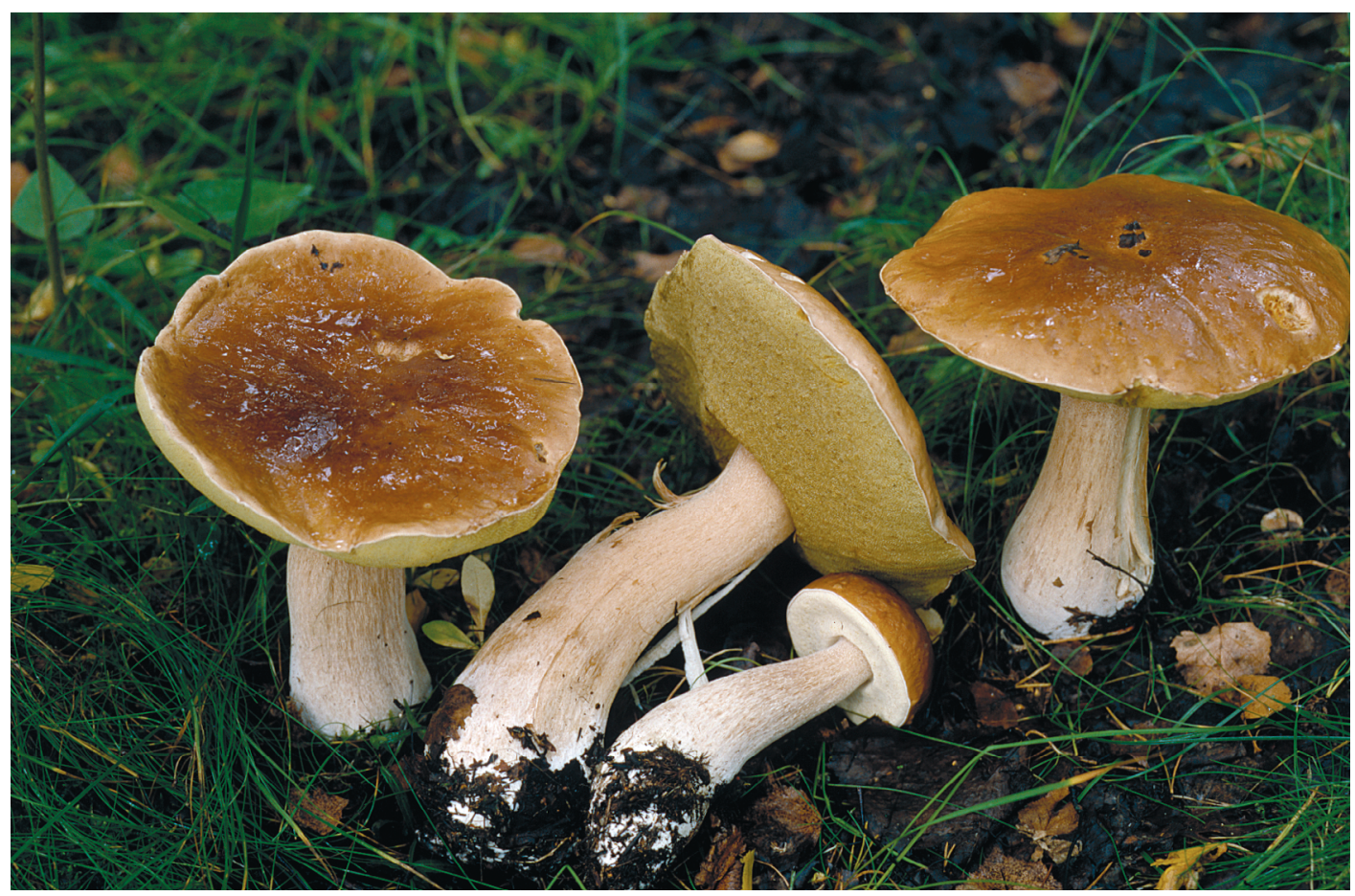

Fig 3. Boletus edulis, Finland, Uusimaa, Vantaa, Veromies, 1992 Korhonen 11110. Photo M. Korhonen. 


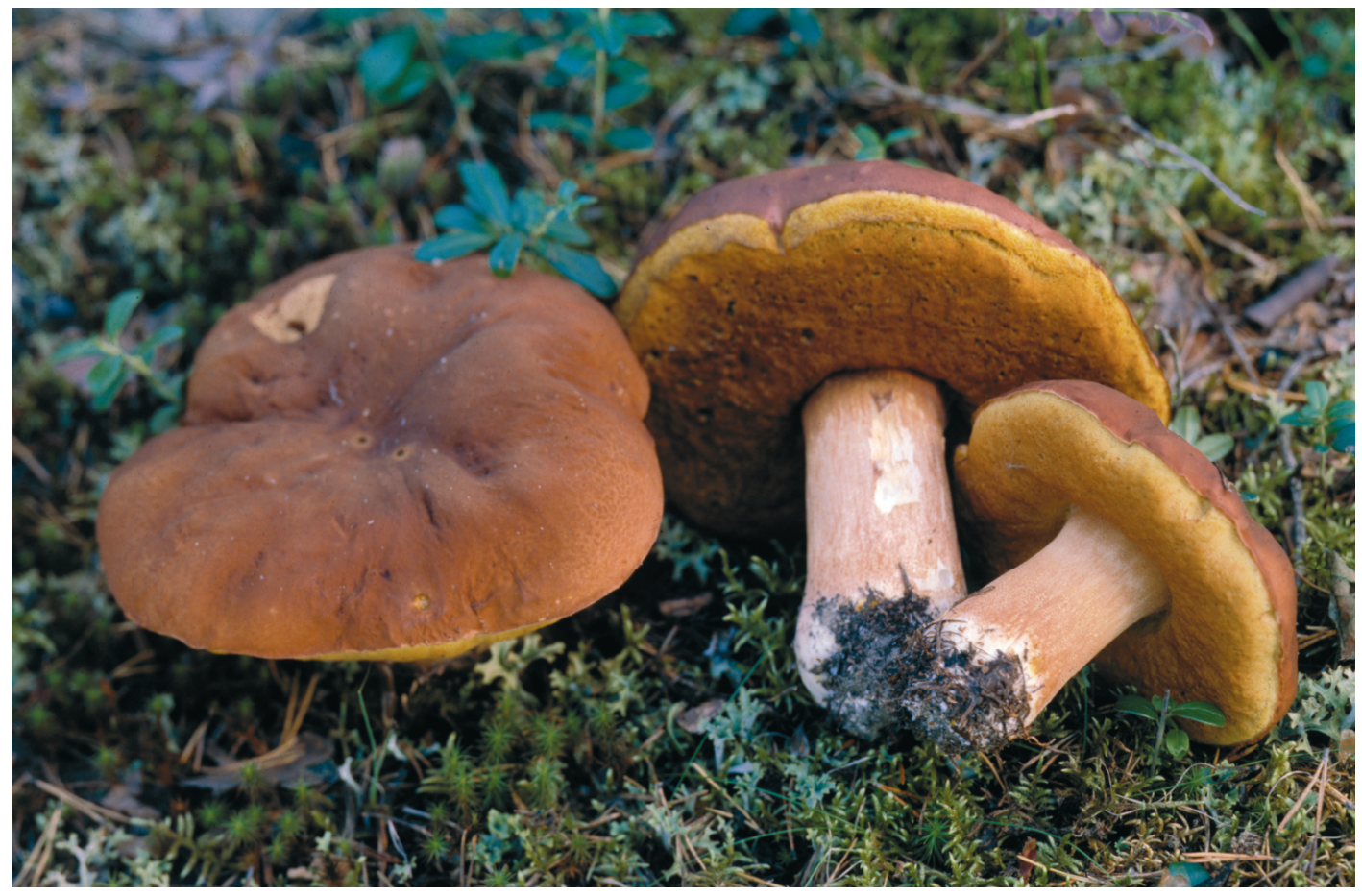

Fig. 4. Boletus pinophilus, Finland, Pohjois-Karjala, Ilomantsi, Mekrijärvi, 1997 Korhonen 12450. Photo M. Korhonen.

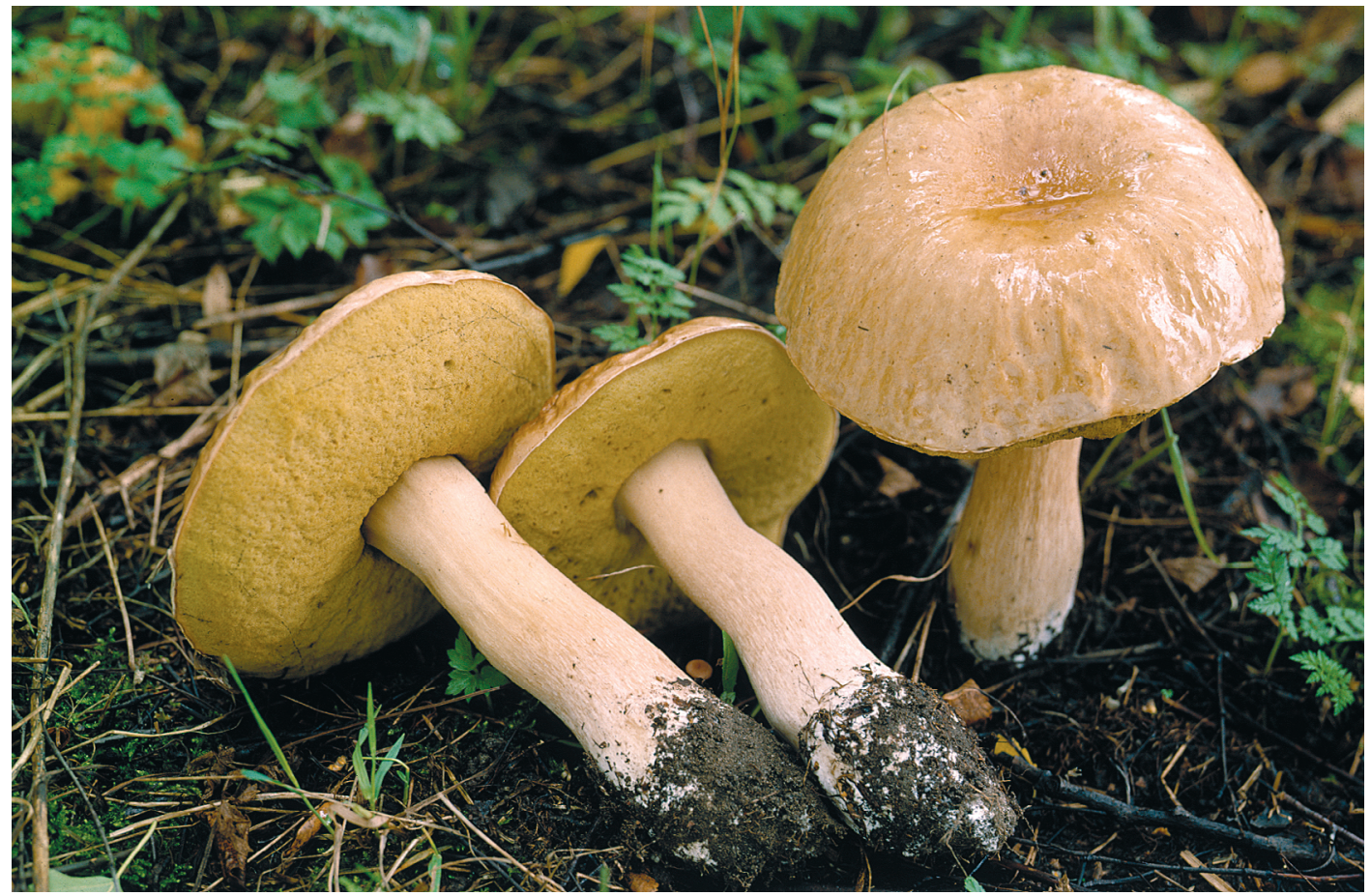

Fig. 5. Boletus betulicola, Finland, Uusimaa, Vantaa, Veromies, 1992 Korhonen 11141. Photo M. Korhonen. 


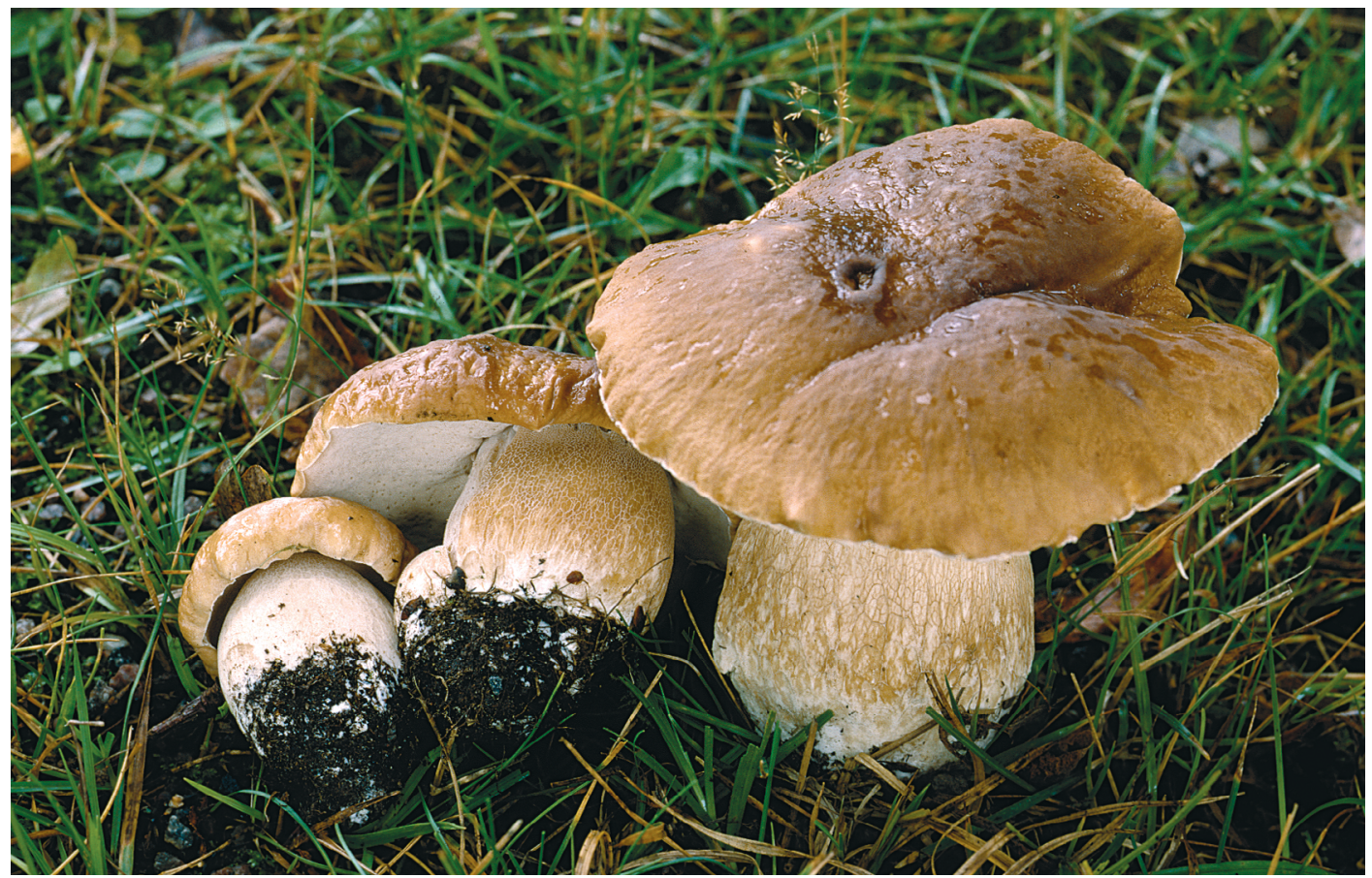

Fig. 6. Boletus reticulatus, Finland, Uusimaa, Helsinki, Malmi, 2008 Korhonen 14810. Photo M. Korhonen.

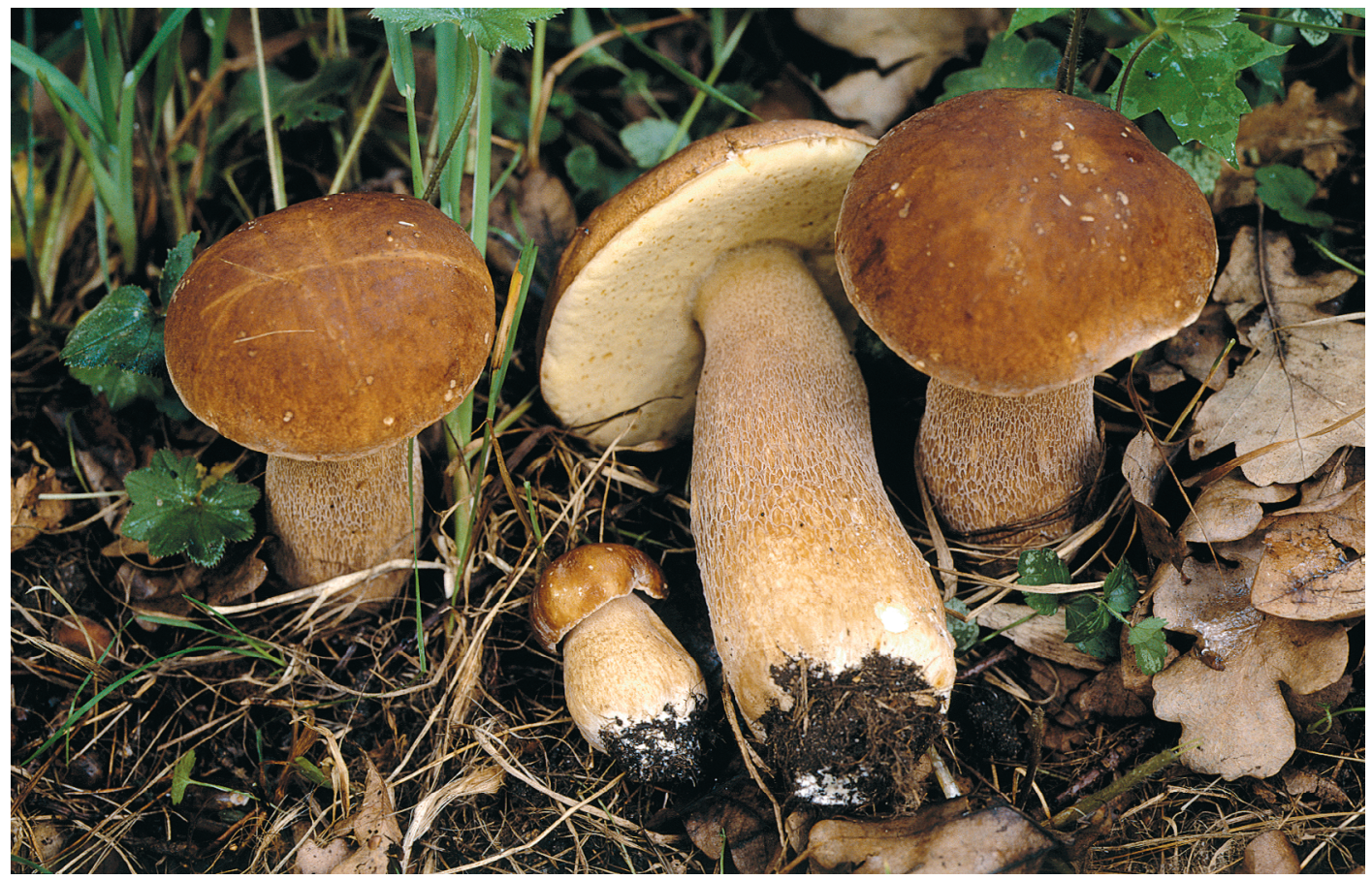

Fig. 7. Boletus aff. reticulatus, Finland, Uusimaa, Kirkkonummi, Ursbyberget, 1995 Korhonen 12017. Photo M. Korhonen. 
honen 12451 photo (ITS GU198985, IGS GU223345); Ukonkangas, 16 Aug 1997 Korhonen 12400 photo (ITS GU198987, IGS GU223346).

4. Boletus betulicola (Vassilkov) Pilát \& Dermek - Figs. 5, 10 and 12, Tables 1-3

Boletus edulis var. betulicola Vassilkov, Edible and poisonous fungi of the central parts of the European districts of the U.S.S.R.: 46.1948.

Boletus betulicola (Vassilkov) Pilát \& Dermek, Hríbovité Huby [Boletaceous Fungi]: 96. 1974.

Pileus 10-20 (-25) cm, pale brownish, brown to dark brown, rarely café-au-lait coloured; cuticle slightly exceeding the margin; surface viscid or even glutinous when wet. Hymenophore tubulate, tubes $1.5-2.5 \mathrm{~cm}$ long, at first yellowish white, then yellowish, with only slight greenish tint, with age outwards swollen. Pores concolorous with tubes, small. Stipe 10-15 (-20) cm, cylindrical or swollen at the base, somewhat slender, whitish when young, later with a brownish tint; with a faint, whitish reticulum, not very clearly distinguishable from the whitish background. Context white, soft. Taste mild, pleasant. Smell pleasant.

Spores 16-18 × 5-6 $\mu \mathrm{m}, \mathrm{Q}=2.7-3.4(500$ spores, 10 collections), $\mathrm{X}(\mathrm{av})=.17 \times 5.6 \mu \mathrm{m}$, $\mathrm{Q}(\mathrm{av})=3.05,. \mathrm{Vm}=279 \mu \mathrm{m}^{3}$, (Fig. 10) fusiform, with a distinct suprahilar depression and pointed apex, smooth, yellowish brown, thick-walled. Basidia 4-spored, 24-31 × 6.5-9 $\mu \mathrm{m}$, clavate. Caulocystidia 40-88 $\times 5-15 \mu \mathrm{m}$, cylindrical or somewhat swollen below. Hyphae of the pileipellis 3-6 $\mu \mathrm{m}$ wide, more or less granulated, variable brown. End-cells of the pileipellis 20-50 $\times$ (10-)15-25 $\mu \mathrm{m}$, fairly short, \pm swollen on the apex.

Ecology and distribution: Boletus betulicola is associated with Betula spp. and occurs in all types of forests with birch, even in the subalpine and alpine heaths with Betula nana.

Comments: Typical for Boletus betulicola are the slender habit, spores with a pointed apex, end-cells of the pileipellis with swollen apex, and habitat with Betula. The cap cuticle is thicker than in other species of the section Boletus and slightly exceeds the margin.

Representative specimens examined: FINLAND. Uusimaa: Espoo, Karhusaari, 16 Sept 1999 Korhonen 12849 (ITS GU198983, IGS GU223359). Kirkkonummi, Urs- byberget, 5 Oct 1997, Korhonen 12436 (ITS GU198982, IGS GU223362), Korhonen 12438 (ITS GU198979, IGS GU223360). Vantaa, Veromies, 6 Sept 2004 Korhonen 11141. Enontekiön Lappi: Kilpisjärvi, Ahdaskuru, 20 Aug 1998 Korhonen 12624 photo, 12634 photo, 22 Aug 2003 Korhonen 13231 photo (ITS GU198981, IGS GU223361); Saana, 19 Aug 2007 Höijer 4512, 21 Aug 2007 Höijer 4534. - NORWAY. Troms: Skibotndalen, 20 Aug 2003 Korhonen 13213 (ITS GU198980).

5. Boletus reticulatus Schaeff. - Figs. 6 and 10, Tables 1-3

Boletus reticulatus Schaeff., Fung. Bavar. Palat. 4: 78.1774.

Pileus 10-20 (-30) cm, ivory to yellowish white when young, later pale yellowish brown to pale greyish brown, sometimes pale brownish yellow, darker when old; edge fairly thin; surface dry, matt, finely tomentose to somewhat fibrillose, in dry weather often finely to coarsely cracking revealing the whitish context. Hymenophore tubulate, tubes $1-2.5 \mathrm{~cm}$ long, at first whitish, then pale greyish yellowish, greyish greenish yellow and somewhat outwards swollen when old. Pores concolorous with tubes, but near the edge of the pileus remaining almost whitish even when old, small. Stipe 10-20 cm, cylindrical or swollen at the base, stout, concolorous or paler than the pileus; with a fine, fairly easily distinguishable reticulum, which is concolorous or slightly darker than the background. Context white, also under the pileipellis. Taste mild, pleasant. Smell strong, pleasant.

Spores $13.5-16 \times 4.5-5.5 \mu \mathrm{m}, \mathrm{Q}=2.7-3.6$ (300 spores, 6 collections), $\mathrm{X}(\mathrm{av})=.15 \times 4.8 \mu \mathrm{m}$, $\mathrm{Q}(\mathrm{av})=3.15,. \mathrm{Vm}=181 \mu \mathrm{m}^{3}$, (Fig. 10) fusiform, smooth, yellowish brown, thick-walled. Basidia 4-spored, 25-30 × 6.5-8 $\mu \mathrm{m}$, clavate but slender. Caulocystidia 55-95 × 7-13 $\mu \mathrm{m}$, cylindrical to somewhat swollen below. Hyphae of the pileipellis aggregated, erect, brownish granulose or completely pale brownish, fragile and easily broken when prepared. The structure is most easily observed in the apex of scale. End-cells of pileipellis 30-60 $(-70) \times 3.5-5 \mu \mathrm{m}$.

Ecology and distribution: Boletus reticulatus is associated with Quercus, Corylus and presumably also with Betula. It is common in temperate areas but become less frequent towards the north and is rare in southern boreal zone.

Comments: Boletus reticulatus has when young pale cap, pale brown reticulum, and pale 

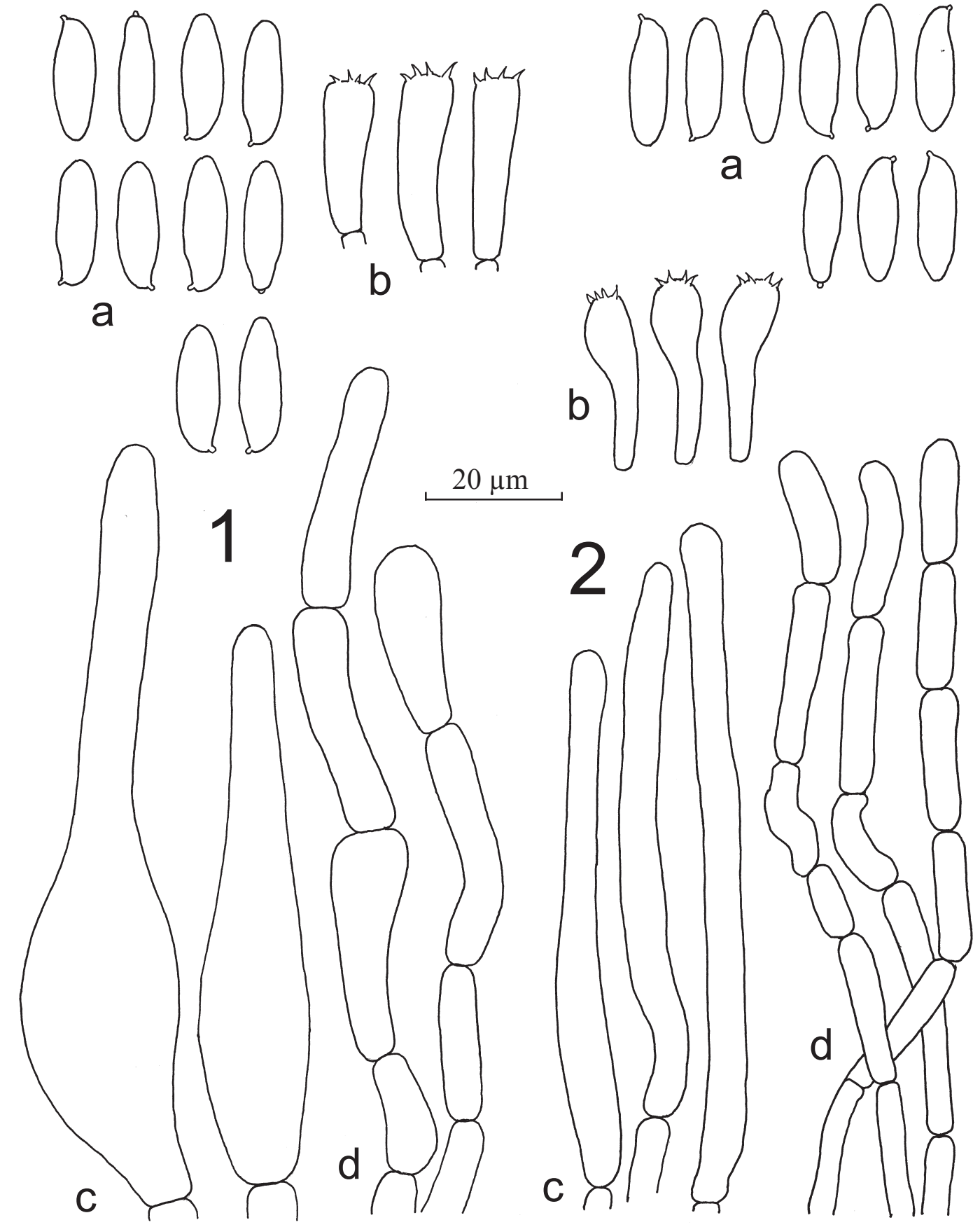

Fig 8. 1) Boletus pinetorum (Korhonen 11925, holotypus). 2) Boletus edulis (Korhonen 11970). - a = spores, $\mathrm{b}=$ basidia, $\mathrm{c}=$ caulocystidia, $\mathrm{d}=$ pileipellis hyphae. - Scale of elements $\times 1000$. Drawings M. Korhonen . 


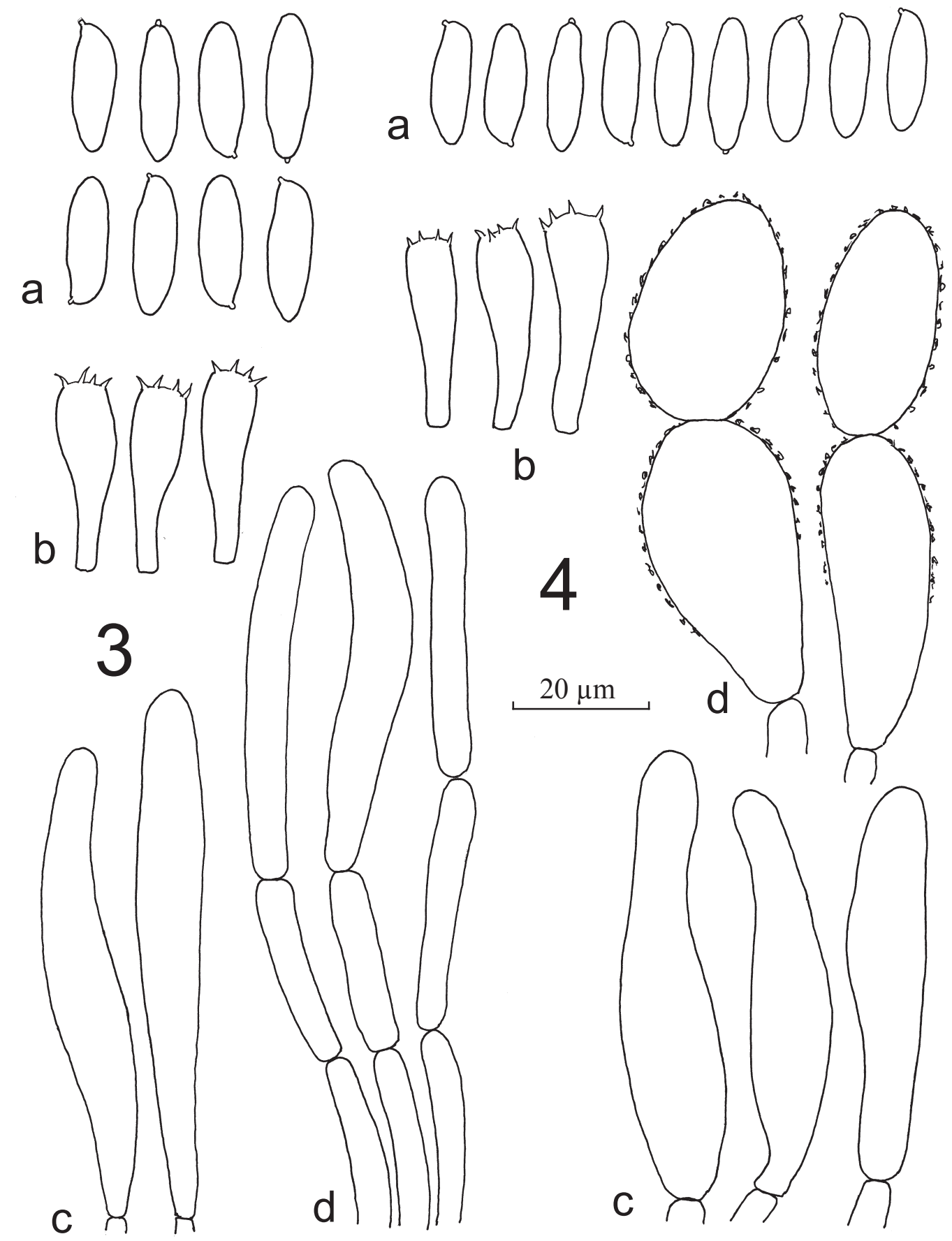

Fig 9. 3) Boletus cf. edulis, with Fagus (Korhonen 12794). 4) Boletus pinophilus (Korhonen 12400). - a = spores, $\mathrm{b}=$ basidia, $\mathrm{c}=$ caulocystidia, $\mathrm{d}=$ pileipellis hyphae. - Scale of elements $\times 1000$. Drawings M. Korhonen. 


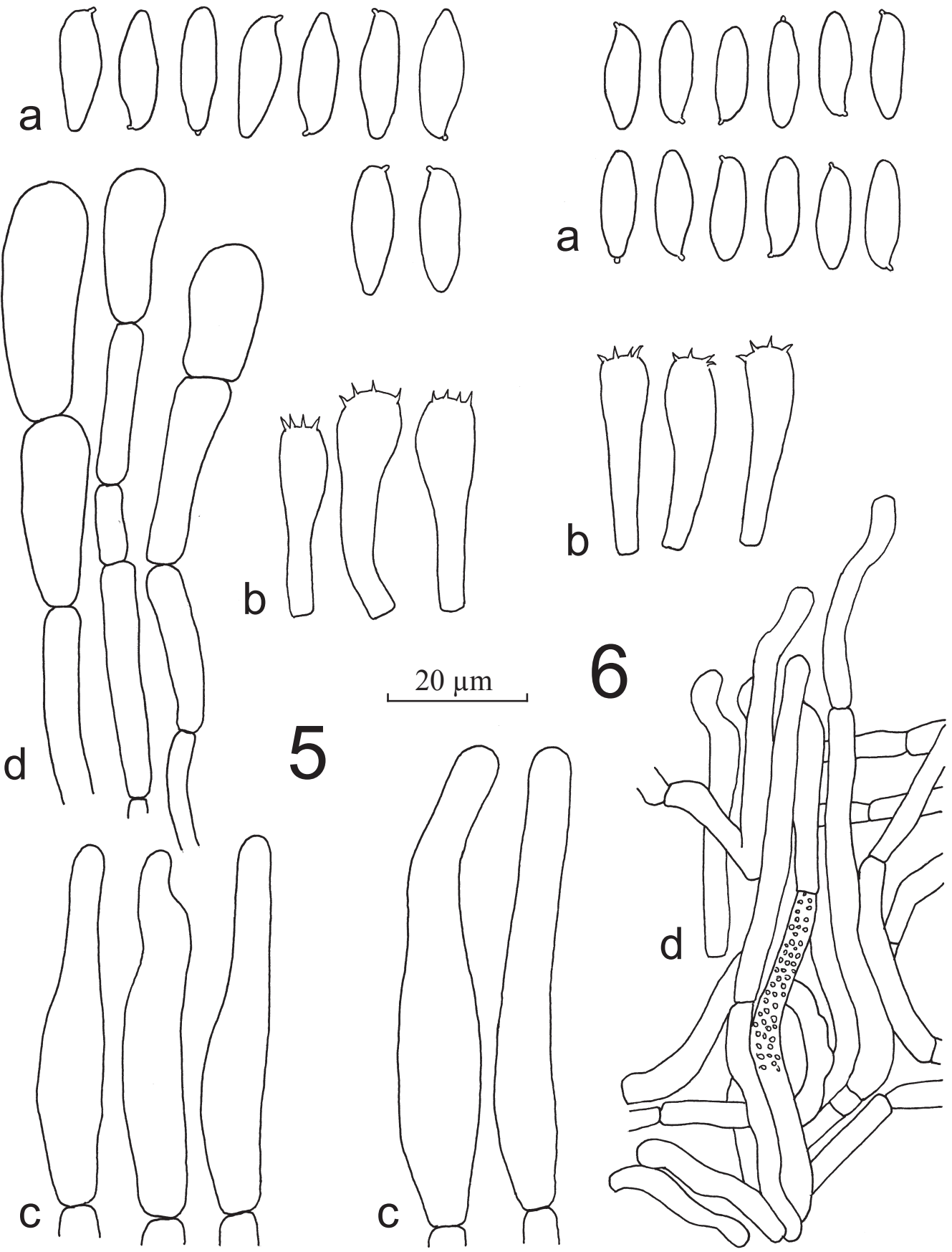

Fig 10. 5) Boletus betulicola (Korhonen 13213). 6) Boletus reticulatus (I. Kytövuori 88-023). $-\mathrm{a}=$ spores, b = basidia, $\mathrm{c}=$ caulocystidia, $\mathrm{d}=$ pileipellis hyphae. - Scale of elements $\times 1000$. Drawings M. Korhonen. 


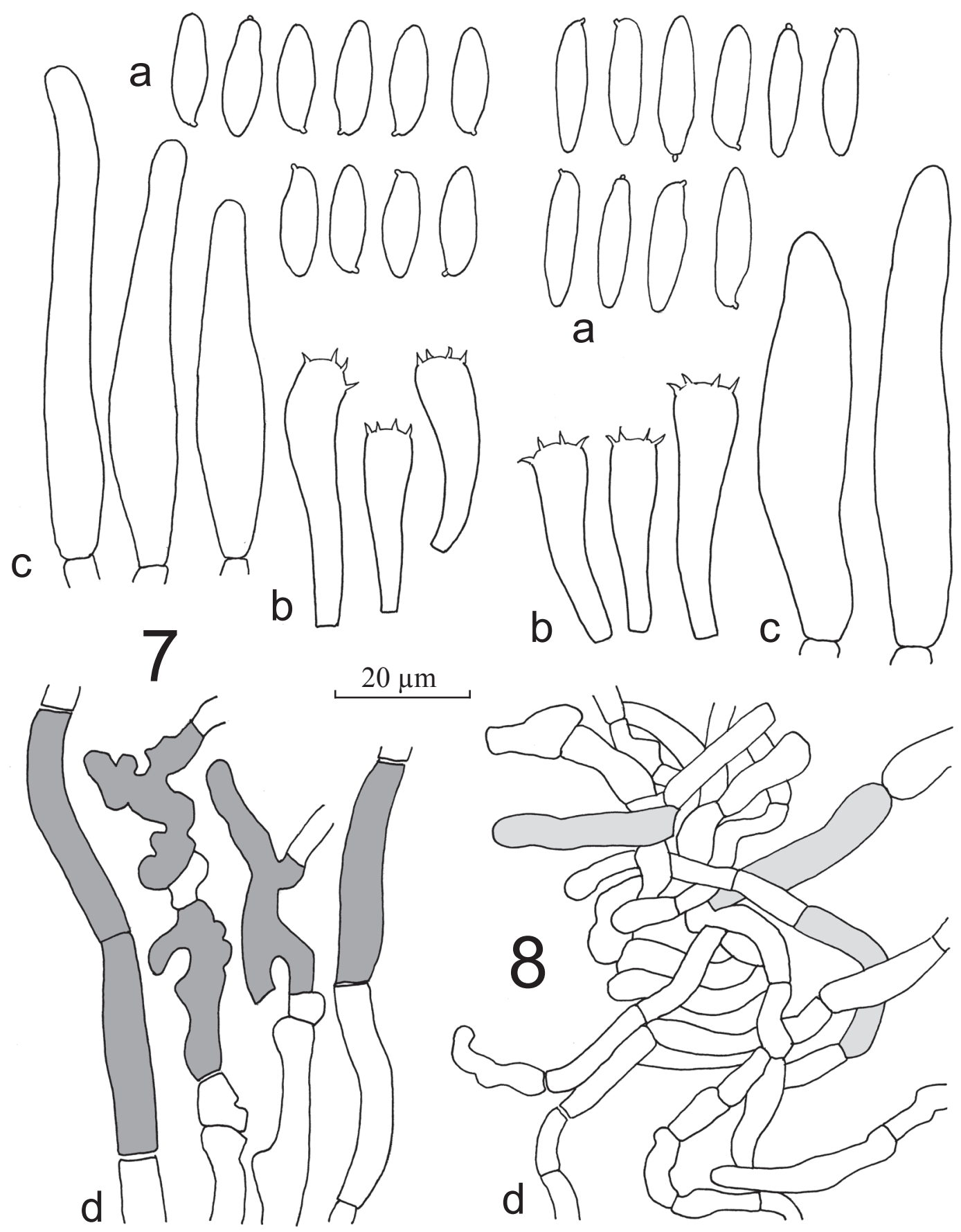

Fig 11. 7) Boletus aff. reticulatus (Korhonen 11183). 8) Boletus edulis var. arcticus (P. Höijer 4550). $-\mathrm{a}=$ spores, $\mathrm{b}=$ basidia, $\mathrm{c}=$ caulocystidia, $\mathrm{d}=$ pileipellis hyphae. - Scale of elements $\times 1000$. Drawings M. Korhonen. 
Table 1. Spore characters of the species in the Boletus sect. Boletus.

\begin{tabular}{|l|l|l|l|l|l|l|}
\hline Species & Size $\mu \mathrm{m}$ & Av. & Q & Q av. & Vm $\mu \mathrm{m}^{3}$ & Comments \\
\hline B. pinetorum & $16.5-19 \times 5.5-6.5$ & $17.5 \times 5.8$ & $2.8-3.3$ & 3.05 & 308 & $\begin{array}{l}\text { fusiform, somewhat broader } \\
\text { than in B. } \text { edulis }\end{array}$ \\
\hline B. edulis & $16-19 \times 5-6$ & $17 \times 5.5$ & $2.7-3.4$ & 3.05 & 269 & fusiform \\
\hline $\begin{array}{l}\text { B. edulis / } \\
\text { Fagus }\end{array}$ & $16-21 \times 5.5-6.5$ & $18 \times 5.9$ & $2.9-3.5$ & 3.2 & 328 & $\begin{array}{l}\text { fusiform, biggest of the } \\
\text { section }\end{array}$ \\
\hline $\begin{array}{l}\text { B. pinophilus } \\
17-20 \times 4.5-6\end{array}$ & $18 \times 5.5$ & $3-3.8$ & 3.4 & 285 & $\begin{array}{l}\text { fusiform, narrowing to both } \\
\text { ends more than in } \text { B. edulis, } \\
\text { especially when seen above }\end{array}$ \\
\hline $\begin{array}{l}\text { B. betulicola } \\
16-18 \times 5-6\end{array}$ & $17 \times 5.6$ & $2.7-3.4$ & 3.05 & 279 & $\begin{array}{l}\text { fusiform, with a distinct } \\
\text { suprahilar depression and } \\
\text { pointed apex }\end{array}$ \\
\hline $\begin{array}{l}\text { B. reticulatus } \\
13.5-16 \times 4.5-5.5\end{array}$ & $15 \times 4.8$ & $2.7-3.6$ & 3.15 & 181 & $\begin{array}{l}\text { fusiform, smallest of the } \\
\text { section }\end{array}$ \\
\hline $\begin{array}{l}\text { B. aff. reticu- } \\
\text { latus }\end{array}$ & $15.5-18 \times 4.5-6$ & $17 \times 5.4$ & $2.8-3.6$ & 3.2 & 259 & $\begin{array}{l}\text { fusiform, with slightly } \\
\text { pointed apex, somewhat } \\
\text { smaller than in } \text { B. edulis }\end{array}$ \\
\hline $\begin{array}{l}\text { B. edulis var. } \\
\text { arcticus }\end{array}$ & $16-21 \times 4.5-5.5$ & $17.8 \times 4.9$ & $3.2-4.4$ & 3.8 & 224 & $\begin{array}{l}\text { narrowly fusiform, with } \\
\text { slightly pointed apex }\end{array}$ \\
\hline
\end{tabular}

Table 2. Caulocystidia of the species in the Boletus sect. Boletus.

\begin{tabular}{|l|l|l|}
\hline Species & Size $\mu \mathrm{m}$ & Comments \\
\hline B. pinetorum & $70-160 \times 13-30$ & big, lageniform \\
\hline B. edulis & $70-110 \times 5-10$ & cylindrical to somewhat swollen below \\
\hline B. edulis / Fagus & $70-110 \times 6-11$ & cylindrical to narrowly pin-like \\
\hline B. pinophilus & $58-66 \times 10-14$ & cylindrical to slightly lageniform \\
\hline B. betulicola & $40-88 \times 5-15$ & cylindrical to somewhat swollen below \\
\hline B. reticulatus & $55-95 \times 7-13$ & cylindrical to somewhat swollen below \\
\hline B. aff. reticulatus & $40-70 \times 4-11$ & cylindrical to somewhat swollen below, abundant \\
\hline B. edulis var. arcticus & $55-95 \times 7-14$ & \pm broadly cylindrical, some with slightly narrower apex \\
\hline
\end{tabular}


Table 3. Characters of the end cells of pileipellis and pileipellis structure of the species in the Boletus sect. Boletus.

\begin{tabular}{|l|l|l|}
\hline Species & $\begin{array}{l}\text { Size of the end cells } \\
\text { of pileipellis }(\mu \mathrm{m})\end{array}$ & Comments \\
\hline B. pinetorum & $30-60 \times 6-12$ & $\begin{array}{l}\text { Cells of pileipellis hyphae long, variably brown, some } \\
\text { very dark. End-cells cylindrical or slightly clavate, } \\
\text { almost hyaline. }\end{array}$ \\
\hline B. edulis & $15-30 \times 5-15$ & $\begin{array}{l}\text { Cells of pileipellis hyphae short, granulated, more or less } \\
\text { brownish. End-cells cylindrical or slightly clavate. }\end{array}$ \\
\hline B. edulis / Fagus & $32-60 \times 4-8$ & $\begin{array}{l}\text { Cells of pileipellis hyphae narrow and cylindrical, with } \\
\text { intracellular pigment. }\end{array}$ \\
\hline B. pinophilus & $25-90 \times 14-35$ & $\begin{array}{l}\text { Cells of pileipellis hyphae more or less granulated and } \\
\text { variable brown. End-cells distinctly inflated, incrusted. }\end{array}$ \\
\hline B. betulicola & $20-50 \times(10-) 15-25$ & $\begin{array}{l}\text { Cells of pileipellis hyphae more or less granulated, } \\
\text { variable brown. End-cells fairly short, } \pm \text { clavate. }\end{array}$ \\
\hline B. reticulatus & $30-60 \times 3.5-5$ & $\begin{array}{l}\text { Pileipellis hyphae aggregated, erected, brownish granu- } \\
\text { lose or completely pale brownish, fragile and easily } \\
\text { broken when prepared. End-cells cylindrical or slightly } \\
\text { clavate. }\end{array}$ \\
\hline B. aff. reticulatus & $\begin{array}{l}\text { (3-50 }(-110) \times 6-9 \\
(-15)\end{array}$ & $\begin{array}{l}\text { Pileipellis hyphae aggregated, erected, dark brown (pa- } \\
\text { rietal pigment) or hyaline, some cells granulated, fragile } \\
\text { and easily broken when prepared. End-cells cylindrical } \\
\text { or slightly clavate. }\end{array}$ \\
\hline B. edulis var. arcticus & $15-30 \times 3-7$ & $\begin{array}{l}\text { Pileipellis hyphae aggregated, hyaline or pale } \\
\text { brownish, fragile and easily broken when prepared. } \\
\text { End-cells cylindrical to somewhat clavate. }\end{array}$ \\
\hline
\end{tabular}


brown epicutis hyphae. The spores are smallest within the section. Hymenophore is thin and does not become swollen outwards as much as in other species of the section Boletus.

Representative specimens examined: FINLAND. Uusimaa: Helsinki, Annala, 12 Sept 1992 Korhonen 11190 photo (ITS GU198974); Malmi, 4 Aug 1988 Kytövuori 88-023 (ITS GU198972); Malmi, 27 Sept 2008 Korhonen 14810 photo. Raasepori, Bromarv, 30 July 1976 Tuomikoski \& Korhonen 1533 photo (ITS GU198973); Framnäs, 8 July 1984 Korhonen 5870. Tuusula, Ruotsinkylä, Metsäntutkimuslaitoksen tutkimusasema, 30 Aug 1994 Kytövuori 94-100.

\section{Boletus aff. reticulatus - Figs. 7 and 11,} Tables 1-3

Pileus 10-25 (-30) cm, dark brown when young, later pale brownish and spot-like discoloured; surface dry, matt, finely tomentose when young later tomentose to fibrillose, in dry weather often finely to coarsely cracking. Hymenophore tubulate, tubes $1-3.5 \mathrm{~cm}$ long, at first whitish, then yellowish white, when old greyish yellow with olivaceous tint. Pores concolorous with tubes, but near the edge of the pileus remaining almost whitish even when old, small. Stipe 10-25 cm, cylindrical or swollen at the base, stout, pale brownish to brown; with distinct, whitish to brownish white reticulum, which is paler than the background. Context white, yellowish near the hymenophore and at some places in the stipe, firm when young, later soft. Taste mild. Smell strong.

Spores $15.5-18 \times 4.5-6 \mu \mathrm{m}, \mathrm{Q}=2.8-3.6(250$ spores, 5 collections), $X($ av. $)=17 \times 5.4 \mu \mathrm{m}$, $\mathrm{Q}(\mathrm{av})=3.2,. \mathrm{Vm}=259 \mu \mathrm{m}^{3}$, (Fig. 11) fusiform, with slightly pointed apex, smooth, yellowish brown, thick-walled. Basidia 4-spored, 27-40 $\times$ 7-8 $\mu \mathrm{m}$, clavate but slender. Caulocystidia 40$70 \times 4-11 \mu \mathrm{m}$, cylindrical to somewhat swollen below, abundant. Hyphae of the pileipellis 5-6 $\mu \mathrm{m}$ wide, aggregated, erect, dark brown (parietal pigment) or hyaline, some cells granulated, fragile and easily broken when prepared. The amount of brown hyphae varies. Structure most easily observed in the point of scale. End-cells of pileipellis 13-50 $(-110) \times 6-9(-15) \mu \mathrm{m}$.

Ecology and distribution: Boletus aff. reticulatus is associated with Quercus, Tilia, Corylus and probably also with Betula. It occurs in temperate to southern boreal regions but becomes less frequent towards north.
Comments: Typical for Boletus aff. reticulatus are dark brown pileus when young, distinct whitish reticulum and the mixture of dark brown and hyaline hyphae in the pileipellis. The spores are fusiform, and with slightly pointed apex. In addition, the brownish tints of the context under the pileipellis are lacking.

The name Boletus reticulatus has long been used for two different species, both associated with Quercus - here called as Boletus reticulatus and $B$. aff. reticulatus. Watling (1970) pointed out the existence of these species in Great Britain and described the characters separating them. Our studies support the distinction. Boletus reticulatus has a pale cap when young, fine, pale brown reticulum, and the smallest spores in the section while $B$. aff. reticulatus has a dark brown pileus when young, distinct whitish reticulum and longer spores. Genetically Boletus reticulatus is well separated from the other species of the section while $B$. aff. reticulatus belongs to the B. edulis group. Van der Linde (2004) proposed the fixing of the name Boletus reticulatus for the pale, small-spored species and that practice is followed here, in Beugelsdijk et al. (2008), and in Knudsen \& Taylor (2008).

Representative specimen examined: FINLAND. Uusimaa: Helsinki, Annala, 17 Sept 1989 Korhonen, 4 Sept 1992 Korhonen 11118 photo; Munkkiniemi, Pikkuniemi, 12 Sept 1994 Korhonen 11183 photo (ITS GU198971), 16 Sept 2007 Korhonen. Kirkkonummi, Ursbyberget 21 Jun 1995 Korhonen 12017 photo.

\section{Boletus edulis var. arcticus (Vassilkov)} Hlaváček - Fig. 11, Tables 1-3

Boletus edulis f. arcticus Vassilkov, Bekyi Grib: 16. 1966.

Boletus edulis var. arcticus (Vassilkov) Hlaváček, Mykologický Sborník 71(1): 9. 1994.

Pileus 4-7 cm, pale ochraceous brown, ochraceous to brown, edge pale; surface dry, in dry weather often finely cracking. Hymenophore tubulate, tubes $1 \mathrm{~cm}$ long, first whitish, then yellowish white. Pores concolorous with tubes, small. Stipe 8-15 cm long, swollen at the base, stout, pale brownish; with distinct, whitish reticulum at the top of the stipe. Context white. Taste mild, pleasant. Smell mild, pleasant.

Spores $16-21 \times 4.5-5.5 \mu \mathrm{m}, \mathrm{Q}=3.2-4.4(72$ spores, 1 collections $), X($ av. $)=17.8 \times 4.9 \mu \mathrm{m}$, 
$\mathrm{Q}$ (av.)=3.8, $\mathrm{Vm}=224 \mu \mathrm{m}^{3}$, (Fig. 11) narrowly fusiform, with slightly pointed apex, smooth, yellowish brown, thick-walled. Basidia 4 -spored, 25-38 $\times 6.5-9 \mu \mathrm{m}$, fairly broadly clavate. Caulocystidia $55-95 \times 7-14 \mu \mathrm{m}, \pm$ broadly cylindrical, some with slightly narrower apex. Hyphae of the pileipellis aggregated, hyaline or pale brownish, fragile and easily broken when prepared. Endcells of pileipellis $15-30 \times 3-7 \mu \mathrm{m}$, cylindrical to somewhat clavate.

Ecology and distribution: Boletus edulis var. arcticus is associated with Betula nana, but might be associated with other dwarf shrubs too. It is also recorded under solitary Betula pubescens subsp. czerepanovii, but there were individuals of Betula nana in the vicinity. Boletus edulis var. arcticus is rare in subalpine to alpine dwarf scrub heathlands in Fennoscandia.

Comments: Typical for Boletus edulis var. arcticus are aggregated epicutis hyphae, narrowly fusiform spores, and habitat with Betula nana. The variety differs markedly from $B$. edulis. The distinct microscopical characters and ecology would support the species level, but further studies are needed for clarifying the taxonomical status.

Representative specimen examined: FINLAND. Kittilän Lappi: Kittilä, Pallastunturi, 23 Aug 2007 Höijer 4550 (ITS GU198978, IGS GU223347).

\section{Discussion}

\section{Field identification}

The colour variation of the pileus can make the identification of the species of the Boletus section Boletus difficult in the field. Most species are, however, associated with one or a few mycorrhizal partners only, and this makes the identification easier. An example of this can be found in the Kilpisjärvi region in North Finland where Pinus and Picea are lacking. Boletus betulicola is very common in the subalpine birch forests of the area whereas in subalpine dwarf scrub heathland B. edulis var. arcticus associated with Betula nana can be found. Other species of the section Boletus have not been recorded from the area (except $B$. pinophilus from Finnish Forest Research Institute's Pinus experimental plot). From the neighbouring area in Norway, Skibotn where also Pinus and Picea grow, B. edulis, B. pinophilus, and $B$. pinetorum can also be found.
Two species of the section are associated with pine, B. pinophilus and B. pinetorum. The former has a dark brown cap, \pm reddish brown pores, and a hymenophore which becomes pale bluish green to rusty brown when bruised or damaged. The latter can most easily be distinguished from $B$. pinophilus and spruce associated B. edulis by the greyish brown pileus colour.

Boletus edulis is associated with spruce and does not grow in pure stands of birch or pine. The colour of the pileus can vary greatly. A taxon looking like B. edulis but associated with Fagus grows in the temperate and hemiboreal regions in Europe. It differs, however, from B. edulis by several microscopical characters and further studies are needed to clarify the taxonomical status of the taxon.

At least two taxa in the $B$. edulis group are associated with birches: $B$. betulicola and B. edulis var. arcticus. The pileus colour of the former can vary greatly and photographs in Dähncke \& Dähncke (1979) and Korhonen (1989) represent unusually pale fruiting bodies. Typically the pileus is darker, sometimes as dark as in B. edulis, but when one encounters a slender Boletus growing near Betula with the pileus cuticle slightly exceeding the margin, it is most likely $B$. betulicola. The best field character for B. edulis var. arcticus is the subalpine to alpine habitat with Betula nana.

Boletus reticulatus grows at least with oak. It has a pale, matt pileus when young and a fine, fairly easily distinguishable reticulum on the stipe, and is concolorous or slightly darker than the background. The other oak associated species $B$. aff. reticulatus has a dark brown cap when young, and a white, distinct reticulum on the stipe. The species also grows with Tilia and Corylus.

\section{Microscopical identification}

Spores: The spore sizes of many species of the section greatly overlap, but can be used for identification in some cases. However, caution should be taken while measuring because most of the spores are immature and only mature spores should be included in the studies. In addition to size, especially the shape of the spores is useful but so far this has not been utilised to the full extent. For example the spore size of $B$. edulis and $B$. betulicola are similar, but the shape is very 


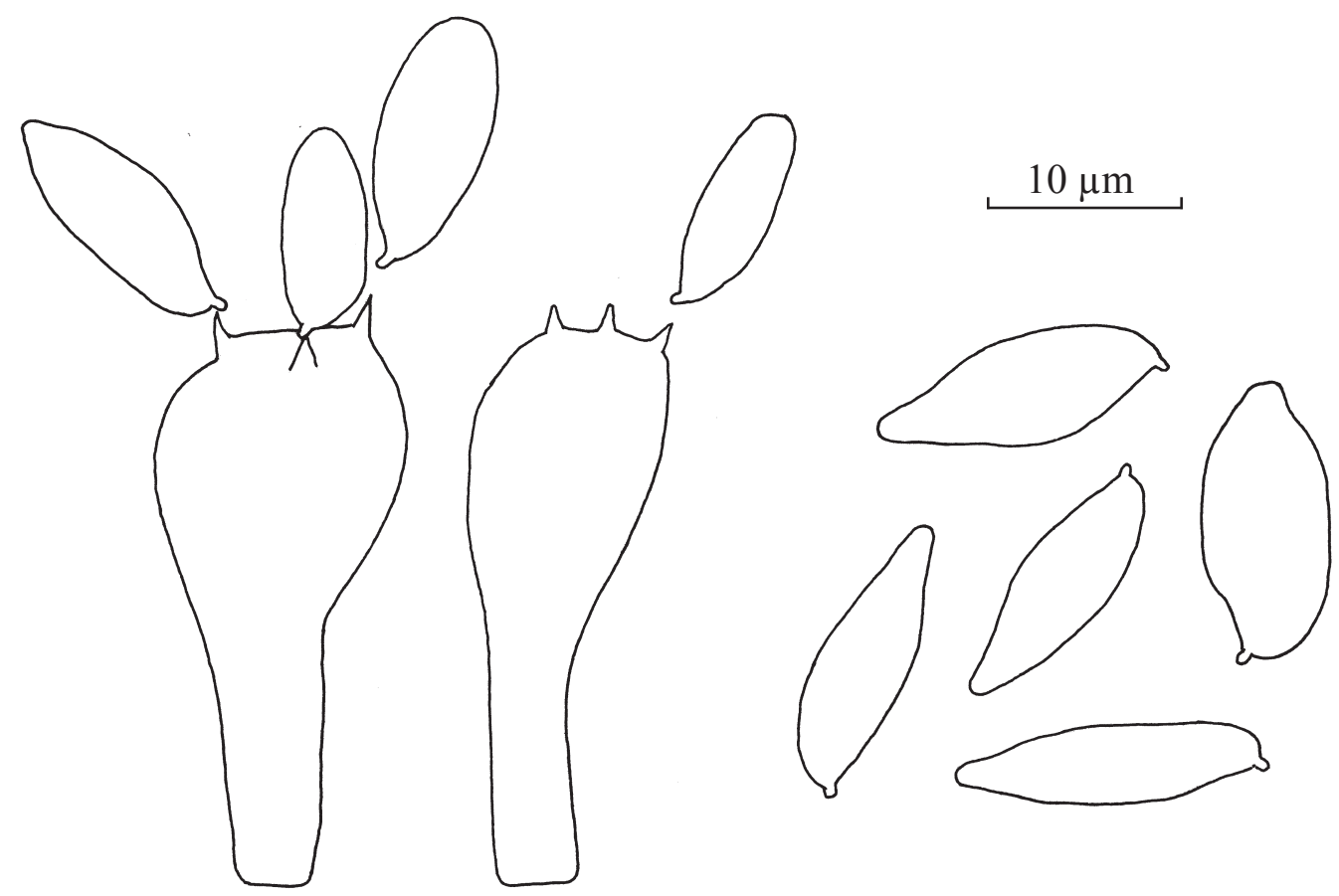

Fig. 12. Boletus betulicola. Hymenium on the stipe: basidia and young, developing spores. The typical pointed apex of the spores is very distinctive in the picture. - Scale $\times 2000$. Drawing M. Korhonen.

different. The spore characters of the taxa in the section Boletus are compared in Table 1.

Hymenium: An interesting feature in the species of the section Boletus is that the reticulum on the stipe is in fact a hymenium which covers the whole stipe from the top to the base (Korhonen 2001, Fig. 12). The meshes are in fact shallow pores and the reticulum consists mostly of cystidia, which are comparable to the cheilocystidia of the pore orifices. Also basidia are present and produce spores, but both are often somewhat deformed and smaller than in the hymenium of the tubes. In addition, basidia with only 1-3 spores are sometimes found. Lower down along the stipe the reticulum is not always easy to distinguish due to the rough surface of the stipe and larger meshes. The continuation of the hymenium onto the stipe seems to be a constant character and the first author has observed it in every fruiting body which he has studied microscopically.
Caulocystidia: The size and shape of caulocystidia are very useful characters in species identification. For studies mature cystidia should be chosen since the differences are best seen in them. The comparison of the characters of caulocystidia is presented in Table 2.

Pileipellis: The pileipellis structure of Boletus includes several good characters for species identification (Table 3 ). The pileipellis mainly consist of two types of hyphae: a) thin main hyphae, and b) broader pigmented hyphae which have either fine or more grained intracellular pigment or look more like concolorous lactiferous-like hyphae. The amount and darkness of the pigments partly causes the colour variation of the pileus, but does not affect to the typical structure of the pileipellis of each species. The end cells of the pileipellis hyphae are the most useful ones for the species identification. They have to be searched carefully amongst the thin main hyphae from the microscopical preparation. In B. pinophilus these 
cells are especially easy to observe, since they are incrusted and clearly different.

Some of the pileipellis hyphae of $B$. reticulatus and B. edulis var. arcticus have pale yellowish brown content and they are locally aggregated forming scale like structures on the pileipellis. In contrast, the pileipellis hyphae of $B$. aff. reticulatus are either hyaline or uniformly dark brown. The complex structure of the pileipellis and big differences between the species reveal that the characters are not continuous and can be used to distinguish discrete morphological entities.

\section{Conclusion}

The morphological differences between the species of the section Boletus are clear, constant, and discontinuous. The ecological requirements of the species are also different. Therefore, a question arises: does $B$. edulis really differ from all the other species in the section in having many different host trees? Or is it a group of closely related species?

The differences between the species are especially clear in the pileipellis. For example, claiming the differences between $B$. edulis and $B$. aff. reticulatus to be intraspecific variation, rather than interspecific, is an underestimation of the observed constant morphological differences. One would expect that these obvious morphological species would also be detected in the genetic level. Based on ITS1, ITS2 and IGS1, however, no grouping within B. edulis coll. could be achieved. Further studies with other new molecular markers may change the situation in the future.

Acknowledgements: We thank Ernest Emmett for revision of the English, and Teuvo Ahti for help with the Latin description. This work was supported by the Ministry of Environment, Finland (YM38/5512/2009).

\section{References}

Aanen, D.K., Kuyper, T.W., Mes, T.H.M. \& Hoekstra, R.F. 2000: The evolution of reproductive isolation in the ectomycorrhizal Hebeloma crustuliniforme aggregate (Basidiomycetes) in northwestern Europe: A phylogenetic approach. - Evolution 54: 1192-1206.

Beugelsdijk, D.C.M., Van der Linde, S. Zuccarello, G.C., den Bakker, H.C., Draisma, S.G.A. \& Noordeloos, M.E. 2008: A phylogenetic study of Boletus section Boletus in Europe. - Persoonia 20, 2008: 1-7.

Binder, M. 1999: Zur molekularen Systematik der Boletales: Boletineae und Sclerodermatinae subordo nov. - PhD thesis, University of Regensburg, Regensburg, Germany.

Breitenbach, J. \& Kränzlin, F. 1991: Pilze der Schweiz, Band 3: 364 - Verlag Mykologia, Luzern.

Den Bakker, H.C., Zuccarello, G.C., Kuyper, T.W.M. \& Noordeloos, M.E. 2004: Host specificity in the ectomycorrhizal genus Leccinum. - New Phytologist 163: 201-215.

Dähncke, R.M. \& Dähncke, S.M. 1979: 700 Pilze in Farbfotos. - AT Verlag Aarau. 686 pp.

Edgar, R.C. 2004: MUSCLE: multiple sequence alignment with high accuracy and high throughput. - Nucleic Acids Research 32: 1792-1797.

Gardes, M. \& Bruns, T.D. 1993: ITS primers with enhanced specifity for basidiomycetes application to the identification of mycorrhizae and rusts. - Molecular Ecology 2: 113-118.

Goloboff, P.S., Farris, S. \& Nixon, K. 2000: TNT (Tree analysis using New Technology) (BETA) ver. 1.0. - Privately published, Tucumán, Argentina.

Henrion, B., Le Tacon, F. \& Martin, F. 1992: Rapid identification of genetic variation of ectomycorrhizal fungi by amplification of ribosomal RNA genes. - New Phytologist 122: 289-298.

Knudsen, H. \& Taylor, A. 2008: Boletus L.:Fr. - In: Knudsen, H. \& Vesterholt, J. (eds.), Funga Nordica, agaricoid, boletoid and cyphelloid genera: 163-168. Nordsvamp, Copenhagen.

Korhonen, M. 1989: Boletus betulicola, front cover. - Sienilehti 41:1 (front cover).

Korhonen, M. 2000: Boletus edulis group in the Nordic countries. - XV Nordic Mycological Congress, Songdal Norway. A poster.

Korhonen, M. 2001: Koivunherkkutatti, Boletus betulicola. - Sienilehti 53: 76-82.

Leonardi, M, Paolocci, F., Rubini, A., Simonini, G. \& Pacioni, G. 2005: Assessment of inter- and intra-specific variability in the main species of Boletus edulis complex by ITS analysis. - FEMS Microbiology Letters 243: 411-416.

Niskanen, T., Liimatainen, K. \& Kytövuori, I. 2008: Two new species in Cortinarius subgenus Telamonia, Cortinarius brunneifolius and C. leiocastaneus, from Fennoscandia (Basidiomycota, Agaricales). - Mycological Progress 7: 239-247.

Singer, R. 1986: The agaricales in modern taxonomy. Fourth edition. - Koelz. Königstein, Germany.

Taylor, A.F.S., Hills, A.E., Simonini, G., Both, E.E. \& Eberhardt, U. 2006: Detection of species within the Xerocomus subtomentosus complex in Europe using 
rDNA-ITS sequences. - Mycological Research 110: 276-287.

Thompson, J.D., Higgins, D.G., \& Gibson, T.J. 1994: Clustal W: improving the sensitivity of progressive multiple sequence alignment through sequence weighting, position specific gap penalties and weight matrix choice. - Nucleic Acid Research 22: 46734680.

Van der Linde, S. 2004: A taxonomic revision of section Boletus in The Netherlands. - Leiden (unpublished).

Watling, R. 1970: Boletaceae; Gomphidiaceae; Paxillaceae. British fungus flora 1. - Royal Bot. Garden, Edinburgh. 126 pp.

White, T.J., Bruns, T., Lee, S. \& Taylor, J. 1990: Amplification and direct sequencing of fungal ribosomal RNA genes for phylogenetics. - In: Michael, A.J., Gelfand, D.H., Sninsky, J.J. \& White, T.J. (eds), PCR protocols: a guide to the methods and applications: 315-322. - New York. Academic Press. 